\title{
Taxonomy and multigene phylogenetic evaluation of novel species in Boeremia and Epicoccum with new records of Ascochyta and Didymella (Didymellaceae)
}

Jayasiri $\mathrm{SC}^{1,2}$, Hyde $\mathrm{KD}^{2,3}$, Jones $\mathrm{EBG}^{4}$, Jeewon $\mathrm{R}^{5}$, Ariyawansa $\mathrm{HA}^{6}$, Bhat $\mathrm{JD}^{7}$, Camporesi $\mathrm{E}^{8}$ and $\mathrm{Kang}_{\mathrm{JC}}{ }^{1}$

${ }^{1}$ Engineering and Research Center for Southwest Bio-Pharmaceutical Resources of National Education Ministry of China, Guizhou University, Guiyang, Guizhou Province 550025, P.R. China

${ }^{2}$ Center of Excellence in Fungal Research, Mae Fah Luang University, Chiang Rai 57100, Thailand

${ }^{3}$ World Agro forestry Centre East and Central Asia Office, 132 Lanhei Road, Kunming 650201, P. R. China

${ }^{4}$ Botany and Microbiology Department, College of Science, King Saud University, Riyadh, 1145, Saudi Arabia

${ }^{5}$ Department of Health Sciences, Faculty of Science, University of Mauritius, Reduit, Mauritius

${ }^{6}$ Department of Plant Pathology and Microbiology, College of BioResources and Agriculture, National Taiwan University, No.1, Sec.4, Roosevelt Road, Taipei 106, Taiwan, ROC.

${ }^{7}$ No. 128/1-J, Azad Housing Society, Curca, P.O. Goa Velha, 403108, India

${ }^{8} 9$ A.M.B. Gruppo Micologico Forlivese "Antonio Cicognani”, Via Roma 18, Forlì, Italy; A.M.B. CircoloMicologico "Giovanni Carini”, C.P. 314, Brescia, Italy; Società per gliStudiNaturalisticidella Romagna, C.P. 144, Bagnacavallo (RA), Italy

*Correspondence: jckang@gzu.edu.cn

Jayasiri SC, Hyde KD, Jones EBG, Jeewon R, Ariyawansa HA, Bhat JD, Camporesi E, Kang JC 2017 - Taxonomy and multigene phylogenetic evaluation of novel species in Boeremia and Epicoccum with new records of Ascochyta and Didymella (Didymellaceae). Mycosphere 8(8), 1080-1101, Doi 10.5943/mycosphere/8/8/9

\begin{abstract}
Four microfungi collected from Italy and Russia are reported. Morphological examination revealed that all four species can be accommodated in the family Didymellaceae (Pleosporales) and more precisely in the genera Ascochyta, Boeremia, Didymella and Epicoccum. ITS, LSU, RPB2 and $\beta$-TUB sequence data were analysed to investigate their phylogenetic relationships. Two new species, Boeremia galiicola and Epicoccum mackenziei are introduced, while Ascochyta medicaginicola and Didymella macrostoma are new records from Russia and Italy. A sexual stage is reported for the first time in Ascochyta medicaginicola. All taxa are described and illustrated with discussion on their taxonomic placement. Multigene phylogenetic analyses provide further evidence to support the introduction of these taxonomic novelties and their classification within the Didymellaceae.
\end{abstract}


Keywords - asexual morph, Dothideomycetes, Pleosporales, rDNA, RPB2, $\beta$-TUB

\section{Introduction}

De Gruyter et al. (2009) introduced Didymellaceae to accommodate the type species Didymella exigua (Niessl) Sacc. Subsequent researchers confirmed the placement of Didymellaceae in Pleosporineae, Pleosporales (Chen et al. 2015). Nineteen genera are presently assigned to the Didymellaceae based on morphology and phylogeny: Allophoma, Ascochyta, Boeremia, Calophoma, Chaetasbolisia, Dactuliochaeta, Didymella, Didymellocamarosporium, Epicoccum, Heterophoma, Leptosphaerulina, Macroventuria, Neoascochyta, Neodidymelliopsis, Neomicrosphaeropsis, Nothophoma, Paraboeremia, Phoma, Phomatodes and Xenodidymella (Hyde et al. 2013, Wijayawardene et al. 2014, 2016, Chen et al. 2015, Thambugala et al. 2016). Ascochyta, Phoma and Staganosporopsis are common pathogens and significant in quarantine decisions (Aveskamp et al. 2010, Zheng et al. 2017). Of the 19 genera, sexual morphs are known for only twelve genera, i.e. Ascochyta, Boeremia, Didymella, Leptosphaerulina, Macroventuria, Neoascochyta, Neodidymelliopsis, Neomicrosphaeropsis, Paraboeremia, Phoma, Stagonosporopsis and Xenodidymella (Wijayawardene et al. 2012a, Woudenberg et al. 2009, Chen et al. 2015, Thambugala et al. 2017).

The family Didymellaceae is characterized by immersed, rarely superficial, separate or gregarious, globose to flattened, ostiolate, ascomata, with 2-5(-8) layers of pseudoparenchymatal cells. Asci are bitunicate, cylindrical to clavate or saccate, 8-spored and arise from a broad hymenium among pseudoparaphyses. Ascospores are mostly hyaline or brownish and 1-septate to multiseptate. Phoma species are common within the Didymellaceae including the representative strain of P. herbarum (CBS 615.75, Boerema et al. 2004), which is type species of the genus (Aveskamp et al. 2010). Presently Phoma herbarum is the type species of as Phoma sensu stricto, which belongs to Didymellaceae (Aveskamp et al. 2010). Coelomycetous or hyphomycetous asexual morphs are formed on natural substrates or culture (Woudenberg et al. 2009, Chen et al. 2015). Epicoccum has a hyphomycetous synanamorph, which is characterized by dark sporodochia with branched conidiophores and mono- to polyblastic, colourless conidiogenous cells that produce coloured, sometimes verruculose, dictyoconidia (Seifert et al. 2011). The coelomycetous asexual stage is characterized by the production of pycnidial conidiomata with monophialidic, doliiform to flask-shaped conidiogenous cells that producing unicellular, hyaline conidia in culture or nature (Aveskamp et al. 2010). In addition to Ascochyta, the genera Calophoma, Didymella, Epicoccum, Heterophoma, Neodidymelliopsis and Xendidymella produce chlamydospores in culture (Woudenberg et al. 2009, Chen et al. 2015).

In the quest to assess fungal diversity of these bitunicate fungi from different regions and hosts, taxa collected from Italy and Russia resulted in two new species and two new records within the family Didymellaceae. The objectives of this study are as follows:

1) To identify and describe the new taxa and new records;

2) To link sexual and asexual morphs (Wijayawardene et al. 2012b) and

3) To investigate their phylogenetic relatedness to other Didymellaceae members based on multigene DNA sequence analyses.

\section{Material and methods}

Sample collection and specimen examination 
Fresh samples were collected from Italy (Arezzo and Forlì-Cesena Provinces) and from Russia (Arkhangelsk region). Slides were prepared and photographed using a Carl Zeiss stereo microscope fitted with an AxioCam ERC 5 S camera. A Motic SMZ 168 Series microscope was used to examine the microscopic characters (peridium, asci, ascospores, pycnidial wall, conidiogenous cells and conidial morphology). Hand sections of the fruiting structures (ascomata and conidiomata) were mounted in water for microscopic studies and photomicrography. All measurements were calculated using Tarosoft Image FrameWork and Adobe Photoshop CS6 Extended v.10.0 software was used for the preparation of figures (Adobe Systems, USA).

Single spore isolation was performed as outlined by Chomnunti et al. (2014). Ascospores which germinated within $24 \mathrm{~h}$ were transferred to malt extract agar (MEA) plates, and incubated at $18-25^{\circ} \mathrm{C}$. After one month of incubation, asexual morph and chlamydospore characters were observed from culture. Axenic cultures were kept for further examination of any asexual morphs from the chlamydospores. However, for E. mackenziei (MFLUCC 16-0335) we could not obtain asexual morphs in culture. Specimens were deposited in the herbarium of Mae Fah Luang University (Herb. MFLU), Herbarium of Cryptogams Kunming Institute of Botany Academia Sinica (HKAS), China Fungarium PDD, New Zealand and the living cultures were deposited in culture collection of Mae Fah Luang University (MFLUCC), Thailand and Culture Collection of Kunming Institute of Botany (KUMCC), China or BIOTEC Culture Collection (BCC), Bangkok, Thailand. Index Fungorum numbers and Facesoffungi numbers were obtained as in Index Fungorum (2016) and Jayasiri et al. (2015). Establishment of new species were based on recommendations outlined by Jeewon \& Hyde (2016).

\section{DNA extraction, PCR amplification and sequencing}

Axenic cultures originating from single ascospores were grown on malt extract agar (MEA) for 14 days at $18-25^{\circ} \mathrm{C}$. Genomic DNA was extracted from the growing mycelium using the Biospin Fungus Genomic DNA Extraction Kit (BioFlux $\left.{ }^{\circledR}\right)$ following the manufacturer's protocol (Hangzhou, P.R. China). DNA amplifications were performed by Polymerase Chain Reaction (PCR). The partial large subunit nuclear rDNA (LSU) was amplified by using primer pairs LROR and LR5 (Vilgalys \& Hester 1990). Primer pairs ITS1 and ITS4 were used for amplification of internal transcribed spacer (ITS) regions (White et al. 1990). The RNA polymerase II second largest subunit (RPB2) gene was amplified by using primers fRPB2 and fRPB2-7cR (Liu et al. 1999, Sung et al. 2007). Beta-tubulin ( $\beta$-TUB) gene was amplified by using primers Btub2fdG and Btub4fd (Woudenberg et al. 2009). Purified PCR profiles were as outlined by Chen et al. (2015) and Jeewon et al. (2002, 2003). PCR products were sequenced by Sangon Biotech (Shanghai), China using same primers as described above.

\section{Phylogenetic analyses}

Appropriate taxa for the analyses were initially selected following BLAST searches of GenBank (http://www.ncbi.nlm.nih.gov/). Multiple sequence alignments were generated with MAFFT v. 6.864b (http://mafft.cbrc.jp/alignment/server/index.html). The alignments were checked visually and improved manually where necessary (Table 1). Four different datasets were used to estimate phylogenies of the four genera (Ascochyta, Boeremia, Didymella and Epicoccum). Ascochyta and Didymella datasets were analysed to investigate phylogenetic relationships of two new records while Boeremia and Epicoccum datasets were analysed to substantiate establishment of new species. All introns and exons were aligned separately. Regions containing many leading or trailing gaps were removed from the LSU, ITS RPB2 and $\beta$ - 
TUB alignments prior to tree building. All sequences were obtained from GenBank. A Maximum likelihood analysis was performed at CIPRES using RAxML v.7.2.8 as part of the "RAxMLHPC2 on TG" tool (Stamatakis et al. 2008, Miller et al. 2010). The general time reversible model (GTR) using proportion of invariable sites were applied with a discrete gamma distribution and four rate classes.

Using MrModeltest 2.2, model of nucleotide substitution was performed (Nylander 2004). The Markov Chain Monte Carlo sampling (MCMC) in MrBayes v.3.0b4 were used to obtain Posterior probabilities (Rannala \& Yang 1996, Huelsenbeck \& Ronquist 2001, Zhaxybayeva \& Gogarten 2002). Six simultaneous Markov chains were run from random trees for 2,000,000 generations and trees were sampled every 100th generation MCMC heated chain was set with a "temperature" value of 0.15 . The distribution of loglikelihood scores were examined to determine stationary phase for each search and to decide if extra runs were required to achieve convergence, using the program Tracer 1.5 (Rambaut \& Drummond 2007). The first 3000 trees were discarded as the burn-in phase. The remaining trees used for calculate posterior probabilities (split frequencies were reached to less than 0.01 in standard deviation). Near to each node are given Bayesian posterior probabilities equal or greater than 0.90. Phylogenetic trees were drawn using FigTree v. 1.4 (Rambaut \& Drummond 2008). New strain sequences generated in this study are deposited in GenBank and accession numbers are under material examined.

Table 1. Comparison of alignment properties of genes and nucleotide substitution models used in the study.

\begin{tabular}{|c|c|c|c|c|}
\hline Genes /loci & ITS & LSU & RPB2 & $\beta$-TUB \\
\hline Alignment strategy & FFT-NS- & FFT-NS- & FFT-NS- & FFT-NS- \\
\hline (MAFFT v6) & $2+$ manual & $2+$ manual & $2+$ manual & $2+$ manual \\
\hline $\begin{array}{l}\text { Nucleotide substitution } \\
\text { models for Bayesian } \\
\text { analysis (determined by } \\
\text { MrModeltest) }\end{array}$ & $\mathrm{GTR}+\mathrm{I}+\mathrm{G}$ & $\mathrm{GTR}+\mathrm{I}+\mathrm{G}$ & $\mathrm{GTR}+\mathrm{I}+\mathrm{G}$ & $\mathrm{GTR}+\mathrm{I}+\mathrm{G}$ \\
\hline
\end{tabular}

\section{Results}

\section{Phylogeny}

The combined ITS, LSU, RPB2 and $\beta$-TUB datasets were analyzed using ML and Bayesian analyses for Ascochyta, Boeremia, Didymella and Epicoccum (Figs 1, 2, 3, 4). The general time reversible model with inverse gamma rates $(\mathrm{GTR}+\mathrm{I}+\mathrm{G})$ was selected by MrModeltest as the best for all four loci (Table 1). The single locus phylogenies of ITS, LSU and $\beta$-TUB resulted in lower resolution than the RPB2 phylogeny at the species level. The ITS, LSU, RPB2 and $\beta$-TUB single gene analyses also resulted in topologies that were congruent and therefore we analysed only the multigene DNA sequence data. All trees generated under different optimality criteria were similar in topology and did not differ significantly with respect to the position of the new taxa (data not shown). Maximum likelihood bootstrap values (MLBS) equal or greater than $70 \%$ and Bayesian posterior probabilities (BPP) greater than 0.90 are given near to each node (Figs. 1, 2, 3 \& 4). 


\section{Phylogeny of Ascochyta}

The final concatenated alignment contained 26 ingroup taxa with a total of 2,748 characters including gaps (1327 characters for LSU, 492 for ITS, 597 for RPB2 and 332 for $\beta$ TUB). The best scoring tree for Ascochyta had final likelihood value of -5979.065132 . The Bayesian analysis resulted in 20000 trees after 2,000,000 generations. The first 3000 trees, representing the burn-in phase of the analyses were discarded, while the remaining tree was used for calculating posterior probabilities in the majority rule consensus tree and is shown in Fig. 1. Maximum likelihood and Bayesian analysis showed that our isolate (MFLUCC 16-0599) grouped with A. medicaginicola (CBS 112.53, CBS 316.90, CBS 404.65) with high statistical support (Fig. 1; 100 MLBS /1 BPP). Therefore A. medicaginicola var. medicaginicola. (MFLUCC 16-0599) is a new record of A. medicaginicola var. medicaginicola from Russia.

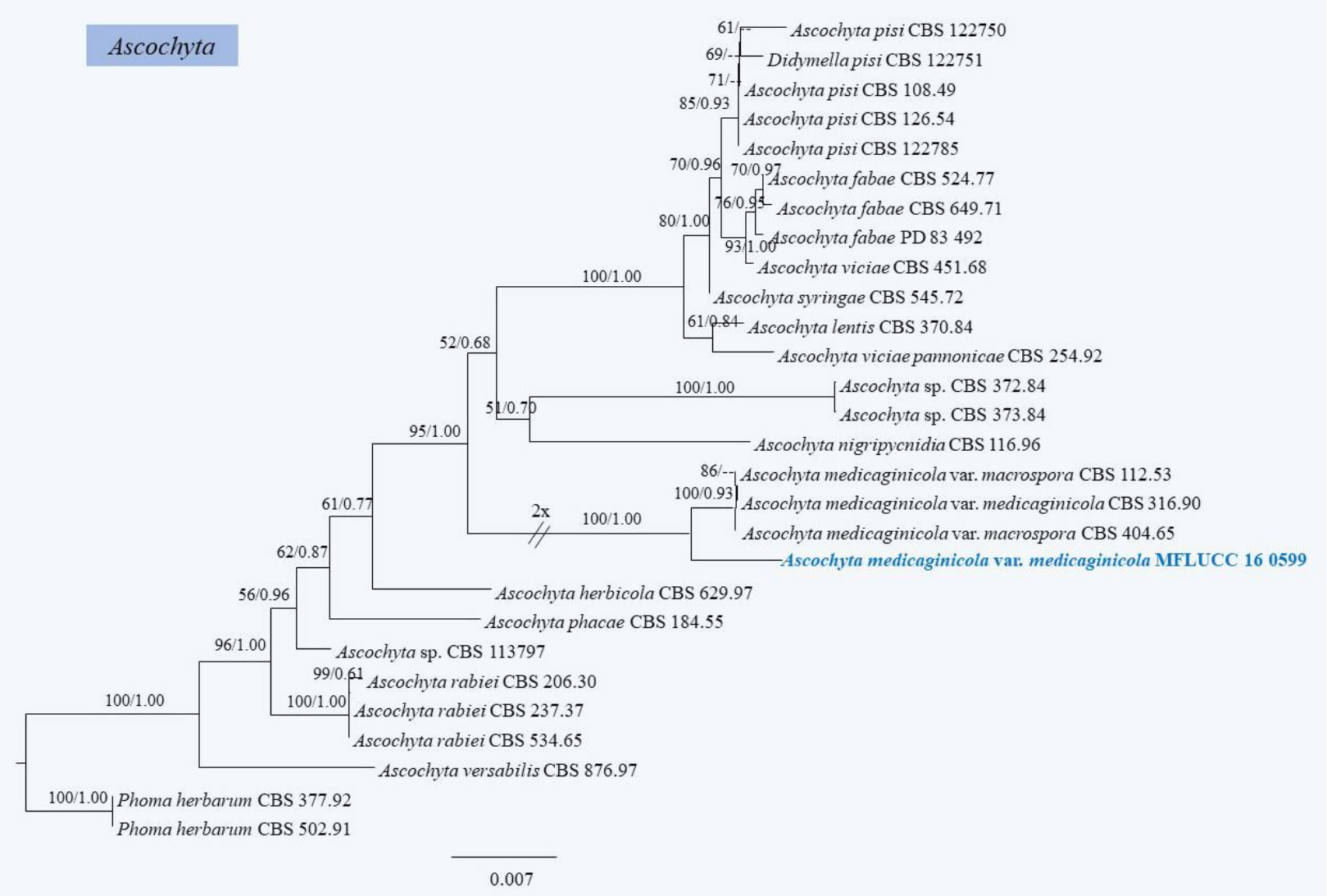

Fig. 1 - Phylogenetic tree inferred from a maximum likelihood analysis based on analyses of a concatenated alignment of LSU, RPB2, ITS and $\beta$-TUB sequence data of 26 strains representing the genus Ascochyta. The RAxML bootstrap support values above $70 \%$ and Bayesian posterior probabilities above 0.90 are given above branches. One branch, indicated by two diagonal lines with the number of times it was shortened to fit the page. The tree is rooted to Phoma herbarum (CBS 377.92; CBS 502.91).

\section{Phylogeny of Boeremia}

The final concatenated alignment contained 34 ingroup taxa with a total of 2, 748 characters including gaps (1328 characters for LSU, 491 for ITS, 597 for RPB2 and 332 for $\beta$ - 
TUB). The best scoring tree for Boeremia genus had final likelihood value of -5435.934917 . The Bayesian analysis resulted in 20000 trees after 2,000,000 generations. The first 3000 trees, representing the burn-in phase of the analyses were discarded, while the remaining tree was used for calculating posterior probabilities in the majority rule consensus tree and is shown in Fig. 2. Maximum likelihood and Bayesian analysis show that Boeremia galiicola is nested in between B. lycopersici, B. foveata and B. hedericola and all these taxa are basal to other Boeremia species (Fig. 2).

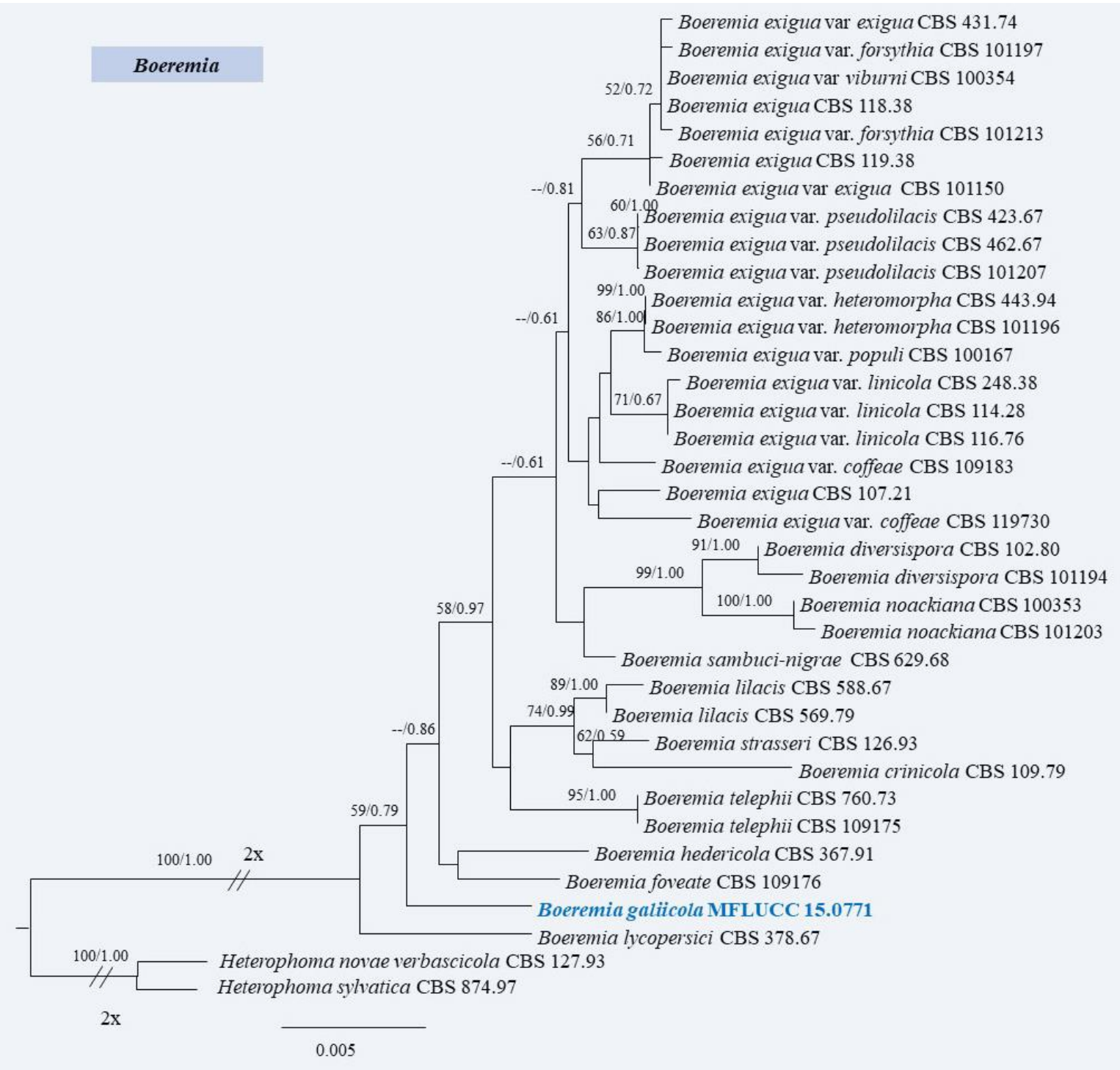

Fig. 2 - Phylogenetic tree inferred from a maximum likelihood analysis based on analyses of a concatenated alignment of LSU, RPB2, ITS and $\beta$-TUB sequence data of 34 strains representing the genus Boeremia. The RAxML bootstrap support values above $70 \%$ and Bayesian posterior probabilities above 0.90 are given above branches. Two branches, indicated by two diagonal lines with the number of times a branch was shortened. The tree is rooted to Heterophoma sp. (CBS 127.93; CBS 874.97). 
Phylogeny of Didymella

The final concatenated alignment contains 64 ingroup taxa with a total 2, 764 characters including gaps (1327 characters for LSU, 492 for ITS, 596 for RPB2 and349 for $\beta$-TUB). The best scoring tree for Didymella genus had a final likelihood value of -11996.202152 . The Bayesian analysis resulted in 20000 trees after 2,000,000 generations. The first 3000 trees, representing the burn-in phase of the analyses were discarded, while the remaining tree was used for calculating posterior probabilities in the majority rule consensus tree and is shown in Fig. 3. In the maximum likelihood and Bayesian analysis, D. macrostoma clusters with other $D$. macrostoma strains with high support (Fig. 3).

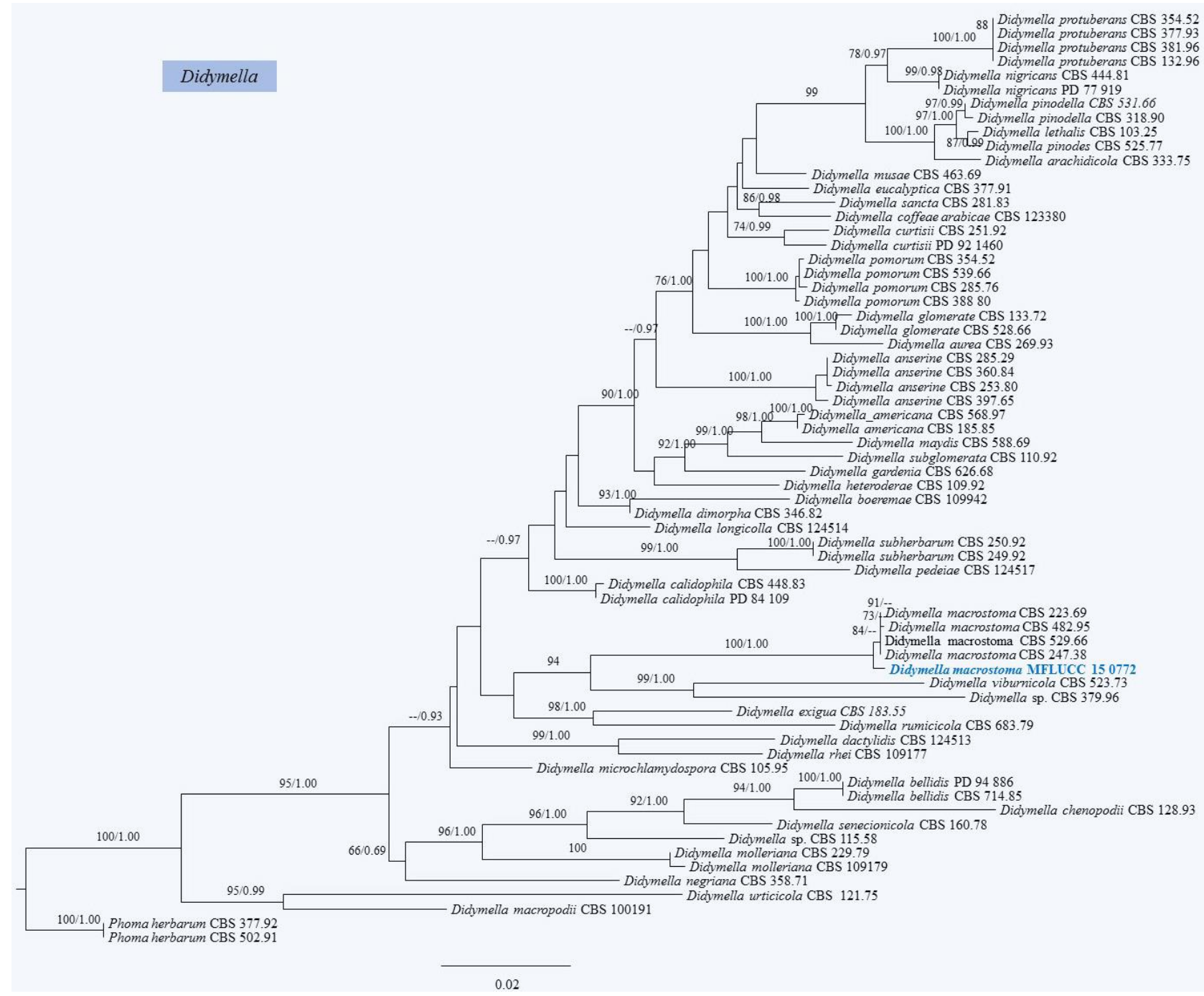

Fig. 3 - Phylogenetic tree inferred from a maximum likelihood analysis based on sequence analyses of a concatenated alignment of LSU, RPB2, ITS and $\beta$-TUB sequence data of 64 strains representing the genus Didymella. The RAxML bootstrap support values above $70 \%$ and Bayesian posterior probabilities above 0.90 are given above branches. The tree is rooted to Phoma herbarum (CBS 377.92; CBS 502.91). 


\section{Phylogeny of Epicoccum}

The final concatenated alignment contained 12 ingroup taxa with a total 2, 763 characters including gaps (1327 characters for for LSU, 493 for ITS, 599 for RPB2, 344 and for $\beta$-TUB). The best scoring tree for Epicoccum genus was had a final likelihood value of 7336.036651. The Bayesian analysis resulted in 20000 trees after 2,000,000 generations. The first 3000 trees, representing the burn-in phase of the analyses were discarded, while the remaining tree was used for calculating posterior probabilities in the majority rule consensus tree and is shown in Fig. 4. Maximum likelihood and Bayesian analyses indicate that Epicoccum mackenziei is closely related to E. nigrum but constitutes an independent lineage with high statistical support (Fig. 4; 100 MLBS /1 BPP).

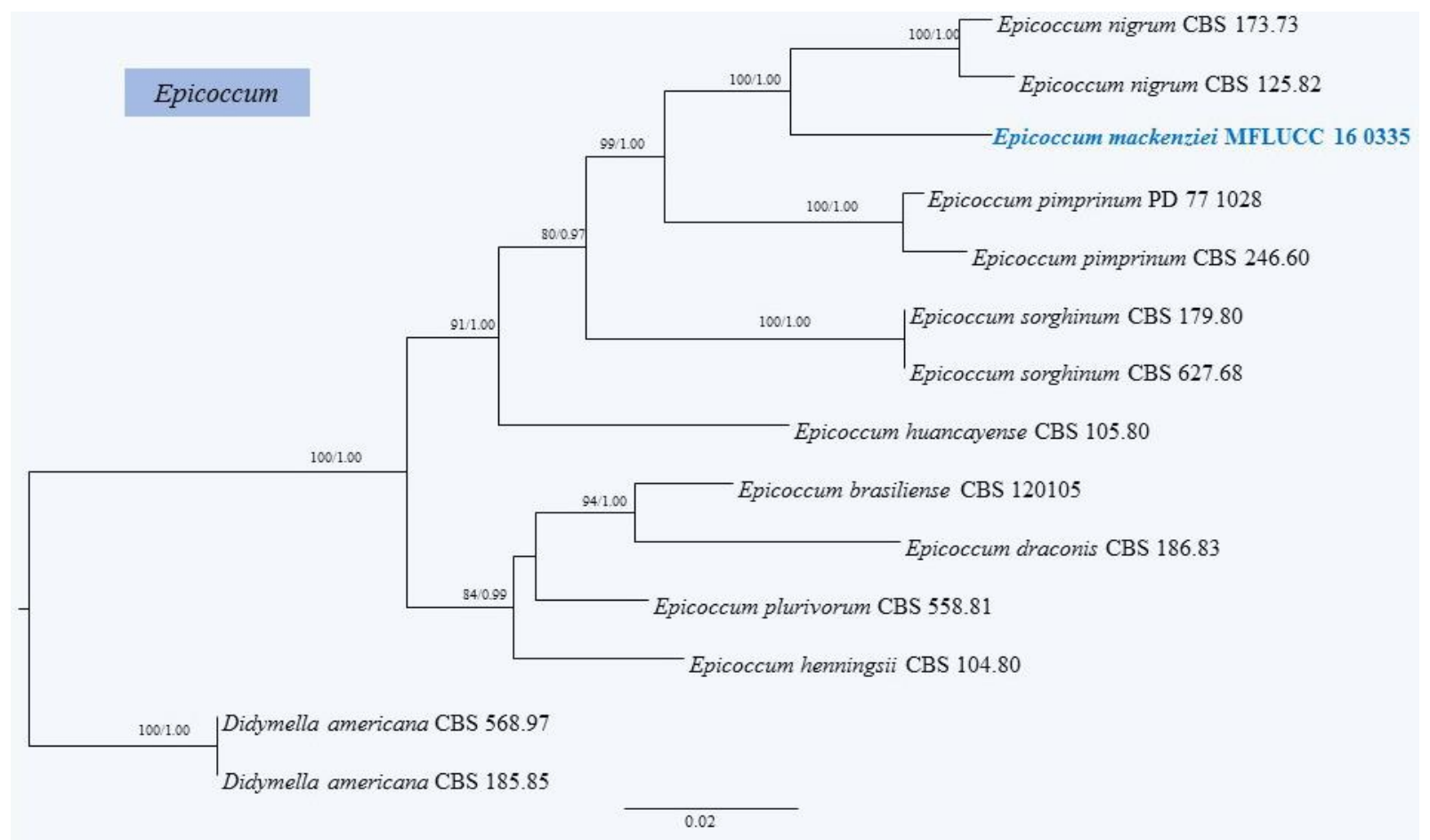

Fig. 4 - Phylogenetic tree inferred from a maximum likelihood analysis based on analyses of a concatenated alignment of LSU, RPB2, ITS and $\beta$-TUB sequence data of 12 strains representing the genus Epicoccum. The RAxML bootstrap support values above $70 \%$ and Bayesian posterior probabilities above 0.90 are given above branches. The tree is rooted to Didymella americana (CBS 568.97; CBS 185.85).

\section{Taxonomy}

Ascochyta medicaginicola var. medicaginicola Q. Chen \& L. Cai 2015

三 Phoma medicaginis var. medicaginis Malbr. \& Roum., Rev. Mycol. 8: 91. 1886.

Facesoffungi number: FoF 02500

Pathogenic on living branches of Melilotus albus noticeable as black, circular dots on the host surface. Sexual morph: Ascomata 165-190 $\mu \mathrm{m}$ high, 170-210 $\mu \mathrm{m}$ wide, scattered or gregarious, superficial to immerse on the substrate, black, subglobose to globose. Ostiole narrow, without periphyses. Peridium 18-41 $\mu \mathrm{m}$ thick, 3-4-layered, equally thick at the apex and base, 
with ostiole thicker than other areas, composed of dark brown cells of textura angularis. Hamathecium lacking pseudoparaphyses. Asci 50-84 × 8-14 $\mu \mathrm{m}, 8$-spored, bitunicate, obclavate to cylindrical, short pedicellate, with a small ocular chamber. Ascospores $12-16 \times 3-5 \mu \mathrm{m}(\bar{x}=$ $14 \times 4.5 \mu \mathrm{m} ; \mathrm{n}=20$ ), obliquely to irregularly uniseriate to biseriate, unequally 2-celled, with rounded, wider apical cell tapering at apex in some, smaller and conical at base, ellipsoid to obovoid, straight, guttulate, hyaline, constricted at the septum, smooth-walled, lacking a mucilaginous sheath. Asexual morph: coelomycetous (Fig. 7). Conidiomata 200-250 $\mu \mathrm{m}$ high, 300-350 $\mu \mathrm{m}$ diam., pycnidial, solitary, scattered or gregarious, globose, semi-immersed to superficial, unilocular, dark brown, without ostiole. Conidiomata wall 15-30 $\mu \mathrm{m}$ wide composed of hyaline to dark brown cells of textura angularis, many layers, equally thickening. Conidiophores reduced to conidiogenous cells, forming from the inner layer of wall cells of the conidiomata. Conidiogenous cells 4-10 $\mu \mathrm{m}$ long $\times 3-5 \mu \mathrm{m}$ wide, hyaline, phialidic, globose to bottle-shaped. Conidia 4-8 $\times 1.5-3 \mu \mathrm{m}$ wide $(\bar{x}=5.5 \times 2 \mu \mathrm{m}, \mathrm{n}=20)$, ellipsoidal to cylindrical, rounded at both ends, hyaline, straight, guttulate, aseptate, thin and smooth-walled.

Culture characters - Colonies 15-20 mm diameter on MEA after one month at $25{ }^{\circ} \mathrm{C}$, grey to brown, outer layer off white, flattened with dense, circular colony middle in yellow, filamentous, aerial, fluffy hyphae; reverse black in the middle, off white hyphae go through black part, white at the edge layer and without any diffusible pigments.

Material examined - RUSSIA, Arkhangelsk Region, Arkhangelsk City, wood waste landfill, on living branch of Melilotus albus Medik. (Fabaceae), 2 August 2015, G.V. Okatov AR 055 (MFLU 15-3195); HKAS, living cultures MFLUCC 16-0599; KUMCC 16-0068, GenBank accession numbers LSU: KX698025, ITS: KX698036, RPB2: KX698033, $\beta$-TUB: KX698029.
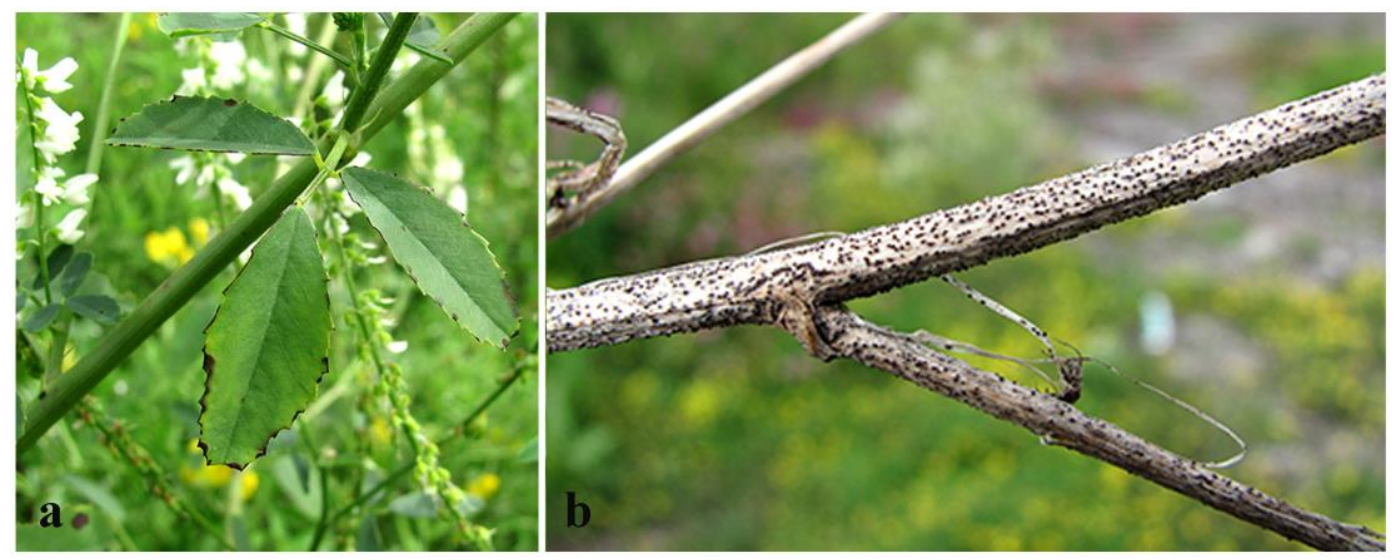

Fig. 5 - a Melilotus albus. host of Ascochyta medicaginicola var. medicaginicola b Symptoms on host branch.

Notes - This is the first record of sexual morph for Ascochyta medicaginicola and characters clearly indicate that it is identical to A. medicaginicola var. medicaginicola (Boerema et al. 2004, Chen et al. 2015). The multigene phylogenetic analysis shows that this collection groups in the Ascochyta medicaginicola clade with $100 \mathrm{MLBS} / 1.00 \mathrm{PP}$ bootstrap support (Fig. 1). This collection also fits with the generic concept of Ascochyta in having erumpent, flattened ascomata with an ostiole, bitunicate, subcylindrical to subclavate, slightly curved asci with short pedicels, and ovoid to ellipsoidal, hyaline, asymmetric, 1-septate ascospores (Jellis \& Punithalingam, 1991, Trapero-Casas \& Kaiser, 1992, Kaiser et al. 1997, Chilvers et al. 2009). 

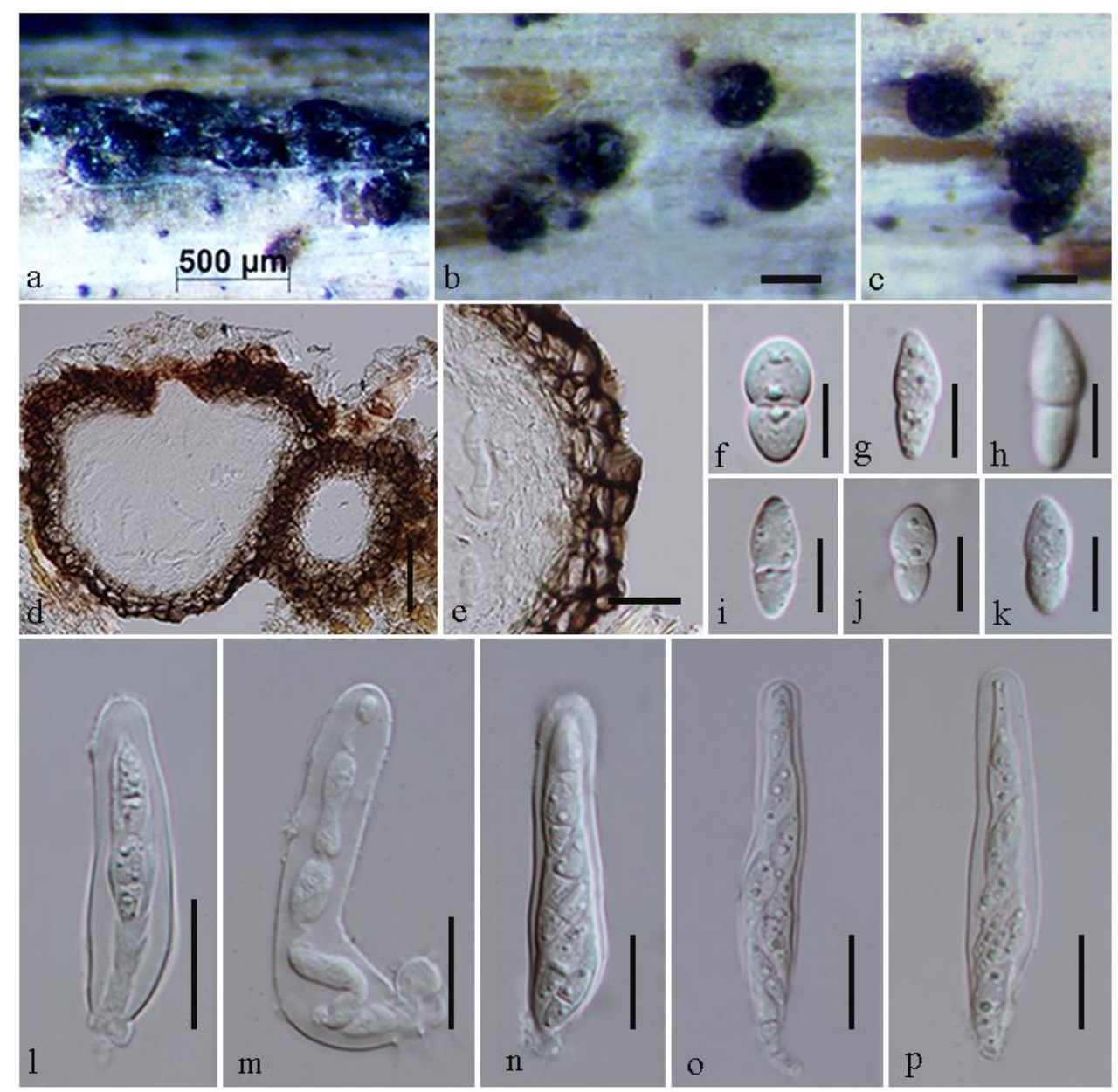

Fig. 6 - Ascochyta medicaginicola var. medicaginicola. a-c Host substrate with ascomata. d Section through ascoma. e Peridium. f-k Ascospores. 1-p Asci. Scale bars: b, c $=200 \mu \mathrm{m}, \mathrm{d}=50$ $\mu \mathrm{m}, \mathrm{e}=30 \mu \mathrm{m}, \mathrm{f}-\mathrm{k}=10 \mu \mathrm{m}, \mathrm{l}-\mathrm{p}=20 \mu \mathrm{m}$.

Boeremia galiicola Jayasiri, Camporesi \& K.D. Hyde, sp. nov.

Index Fungorum number: IF552360, Facesoffungi number: FoF 02501.

Figs 8-9

Etymology: The specific epithet galiicola is based on the host genus from which the holotype was collected.

\section{Holotype: MFLU 15-2279}

Saprobic on a dead stem of Galium sp., forming black circular spots on the host surface. Sexual morph: Ascomata 125-200 (-270) $\mu \mathrm{m}$ high $\times 150-250 \mu \mathrm{m}$ wide $(\bar{x}=180 \times 200 \mu \mathrm{m}, \mathrm{n}=10)$, immersed, without subiculum covering the host, solitary, globose to subglobose, brown to dark brown. Ostiole central, without periphyses. Peridium 30-60 $\mu \mathrm{m}$ wide, $6-8$ rows of cells, with outer part comprising rows of dark brown cells, with inner 3-4 row, comprising hyaline cells of textural angularis. Hamathecium 1.5-2 $\mu \mathrm{m}$ wide, filiform to cylindrical pseudoparaphyses. Asci 65-81 $\times 7-11 \mu \mathrm{m}(\bar{x}=78 \times 9 \mu \mathrm{m}, \mathrm{n}=20), 8$-spored, bitunicate, fissitunicate, slightly curved, cylindric-clavate, short-pedicellate, smooth-walled, apically rounded, with an ocular chamber. Ascospores 17-22 $\times 2.5-5 \mu \mathrm{m}(\bar{x}=20 \times 4 \mu \mathrm{m}, \mathrm{n}=20)$, ellipsoid to obovoid, hyaline, 1-septate, constricted at septum, 1-3-seriate, overlapping, widest at the center and tapering toward narrow ends, straight or slightly curved, guttulate, thick and smooth-walled. Asexual morph: 
coelomycetous (Fig. 9). Conidiomata 70-80 $\mu \mathrm{m}$ high, 90-100 $\mu \mathrm{m}$ diam., pycnidial, globose, separate, lacking ostioles. Conidiophores 4-7.5 $\mu \mathrm{m}$ long $\times 0.5-1 \mu \mathrm{m}$ wide, attached together in a bunch, cylindrical, hyaline. Conidiogenous cells $2-3.5 \mu \mathrm{m}$ long $\times 0.5-1 \mu \mathrm{m}$ wide, holoblastic, cylindrical, hyaline, smooth, rounded at tip. Conidia $2.5-3.5 \mu \mathrm{m}$ long $\times 0.5-1.5 \mu \mathrm{m}$ wide, hyaline, cylindrical, truncate at both ends, aseptate, smooth-walled.

Culture characters - Ascospores germinated on MEA within $24 \mathrm{~h}$ and germ tubes produced from an end. Colonies growing on MEA, reaching $30 \mathrm{~mm}$ diam. after 5 days at 16$18^{\circ} \mathrm{C}$, flat, margin crenate, forward white to olivaceous grey, reverse yellowish brown, fine mycelium, medium dense to dense, septate, hyaline.
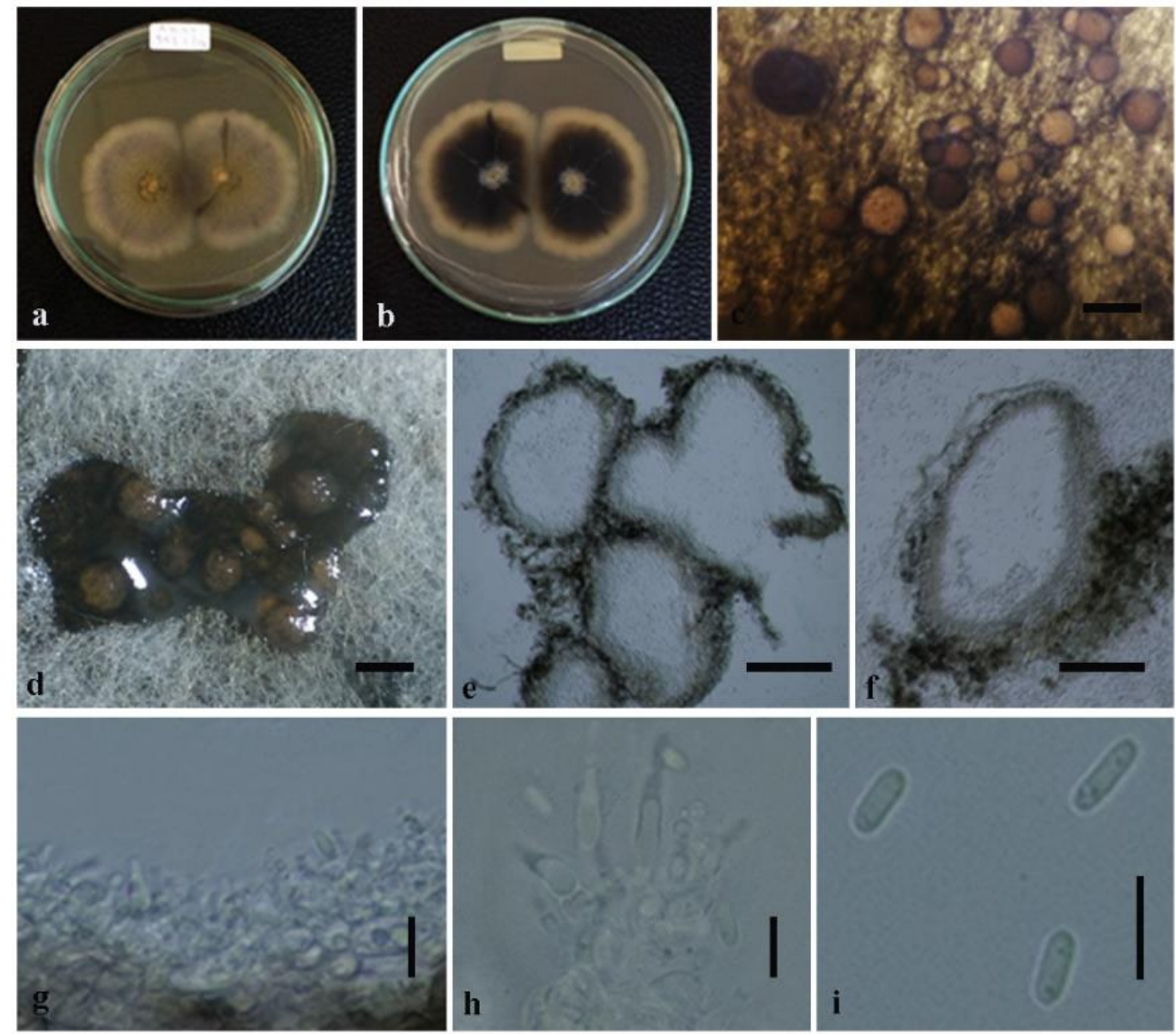

Fig. 7 - Asexual morph of Ascochyta medicaginicola var. medicaginicola (from culture). a Top view of colony on PDA. b Reverse view of colony. c, d Conidiomata in culture. e, f Section through conidiomata. $\mathrm{g}$, h Conidiogenous cells. i Conidia. Scale bars: $\mathrm{a}, \mathrm{b}=3 \mathrm{~cm}, \mathrm{c}, \mathrm{d}=200 \mu \mathrm{m}$ $\mathrm{e}, \mathrm{f}=100 \mu \mathrm{m}, \mathrm{g}=20 \mu \mathrm{m}, \mathrm{h}, \mathrm{i}=10 \mu \mathrm{m}$.

Material examined - ITALY, Province of Arezzo [AR], Papiano Alto - Stia, on dead aerial stem of Galium sp. (Rubiaceae), 12 May 2014, E. Camporesi IT1866 (MFLU 15-2279, holotype); (isotype in PDD), ex-type living culture, MFLUCC 15-0771; KUMCC 16-0069; BCC, GenBank accession numbers LSU: KX698026, ITS: KX698037, $\beta$-TUB: KX698030.

Notes - The genus Boeremia represents species that are morphologically similar to what is currently known as Phoma exigua Desm. (Aveskamp et al. 2010), but molecular data separates 
them into two distinct groups (Aveskamp et al. 2010). Boeremia galiicola fits into the generic concept of Boeremia in having subglobose pseudothecial ascomata, 8-spored, bitunicate, subcylindrical to subclavate asci and ellipsoidal, 1-septate ascospores (Aveskamp et al. 2010). Molecular data indicate that Boeremia galiicola is phylogenetically distinct from other Boeremia species. A close phylogenetic affinity is noted between Boeremia lycopersici (Cooke) Aveskamp et al. and B. galiicola (Fig. 2), but pairwise sequence alignment of LSU, ITS and $\beta$-TUB reveals a difference of 2, 3 and 12 base pair respectively, and therefore, they are not conspecific. The sexual morph is only rarely recorded for Boeremia lycopersici in nature, with subglobose ascomata, up to $300 \mu \mathrm{m}$ diam., asci cylindrical or subclavate, measuring 50-95 $\times 6-10 \mu \mathrm{m}$, always 8-spored, biseriate and ascospores ellipsoid, measuring 12-18 $\times 5-6 \mu \mathrm{m}$, uniseptate (Aveskamp et al. 2010). Boeremia galiicola shares these characters, however, it differs from $B$. lycopersici in characters of ostiole, peridium and hamathecium. Boeremia galiicola is only the second sexual morph recorded for this genus.

Didymella macrostoma (Mont.) Q. Chen \& L. Cai 2015

Figs $10-11$

Facesoffungi number: FoF 02502

Saprobic on a dead branch of Ailanthus altissima (P. Mill), noticeable as minute black dots on host surface. Sexual morph: Ascomata $100-150 \mu \mathrm{m}$ high $\times 125-175 \mu \mathrm{m}$ wide $(\bar{x}=132$ $\times 154 \mu \mathrm{m}, \mathrm{n}=10$ ), immersed or erumpent, globose to subglobose, solitary or scattered, brown to dark brown, without subiculum covering host. Ostiole central, opening to the outside. Peridium 10-23 $\mu \mathrm{m}$ wide, equally thickened, comprising dark brown cells of textura angularis. Hamathecium without pseudoparaphyses. Asci 82-95 $\times 9-13 \mu \mathrm{m}(\bar{x}=89 \times 11 \mu \mathrm{m}, \mathrm{n}=10)$, 8spored, bitunicate, fissitunicate, cylindric-clavate, smooth-walled, slightly curved, apically rounded, short pedicellate, with an ocular chamber. Ascospores 18-20 × 5-7 $\mu \mathrm{m}(\bar{x}=19 \times 6 \mu \mathrm{m}$, $\mathrm{n}=20$ ), 1-2-seriate, overlapping in the ascus, ellipsoid to obovoid, hyaline, 1-septate, constricted at the septum, lower cell longer and narrower than upper cell, widest at the center and tapering towards the end, straight or slightly curved, thin and smooth-walled. Asexual morph: coelomycetous (Fig. 11). Conidiomata 150-250 $\mu \mathrm{m}$ high, 250-350 $\mu \mathrm{m}$ diam., pycnidial, globose, superficial to subperidermal, unilocular, separate, thin-walled, non-ostiolate. Conidiomata wall 11-21 $\mu \mathrm{m}$ wide, composed of 2-3 layers, outer dark brown and inner hyaline cells of textura angularis. Conidiophores reduced to conidiogenous cells. Conidiogenous cells 6-11 × 3-5 $\mu \mathrm{m}$, holoblastic, hyaline, smooth-walled, short, unbranched, globose, formed from the innermost layer of wall cells. Conidia 6-11 $\times 2.5-5 \mu \mathrm{m}(\bar{x}=7.5 \times 3.3 \mu \mathrm{m} ; \mathrm{n}=20)$, hyaline, oval to globose, guttulate, rounded at both ends, aseptate, smooth-walled.

Culture characters - Ascospores germinated on MEA and germ tube produced from an end within $24 \mathrm{~h}$. Colonies reaching $40-50 \mathrm{~mm}$ diam. after 7 days at $16-18^{\circ} \mathrm{C}$ on MEA, no clear margin, upper dark brown to grey and covered by white mycelia, lower dark brown, when reached maximum growth reddish grey and formed asexual structures, fine mycelium, medium dense to dense, septate, hyaline.

Material examined - ITALY, Province of Forlì-Cesena [FC], near Lago Pontini - Bagno di Romagna, on dead aerial branch of Ailanthus altissima (Mill.) Swingle (Simaroubaceae), 21 May 2015, E. Camporesi IT2501 (MFLU 15-1319); HKAS, living cultures MFLUCC 15-0772; KUMCC 16-0070, GenBank accession numbers LSU: KX698027, ITS: KX698038, RPB2: KX698034, $\beta$-TUB: KX698031. 



Fig. 8 - Boeremia galiicola (from holotype). a, b Ascomata on host surface. c, d Sections through ascomata. e Peridium. f Pseudoparaphyses. g-j Asci. k-o Ascospores. p Germinated ascospore. Scale bar: $\mathrm{c}, \mathrm{d}=100 \mu \mathrm{m}, \mathrm{e}, \mathrm{g}-\mathrm{j}, \mathrm{p}=20 \mu \mathrm{m}, \mathrm{e}, \mathrm{g}=30 \mu \mathrm{m}, \mathrm{f}, \mathrm{k}-\mathrm{O}=10 \mu \mathrm{m}$.

Notes - The genus Didymella was emended to accommodate Peyronellaea and several other associated phoma-like species that are phylogenetically related to D. exigua the type species of Didymella (Chen et al. 2015). Our fungus was found as the sexual morph in nature but 
produced the asexual morph in culture. The collection can be accommodated in Didymella as it is characterized by having immersed, flattened ascomata with ostioles, bitunicate, subcylindrical to subclavate, slightly curved asci with short pedicels and cymbiform to ellipsoidal, hyaline, asymmetrical aseptate ascospores. Our isolate is phylogenetically close to D. macrostoma (Mont.) Q. Chen \& L. Cai (CBS 223.69, CBS 482.95, CBS 529.66 and CBS 247.38) with only three base pair differences in the RPB2 gene. In addition, it is similar in having globose to irregular confluent pycnidia, globose to bottle-shaped conidiogenous cells, and subglobose to ellipsoidal, hyaline ascospores with guttules. However, the non-ostiolate pycnidia are different from $D$. macrostoma (MFLUCC 15-0772). Our collection of D. macrostoma (MFLUCC 15-0772) and D. sancta (Aveskamp, Gruyter \& Verkley) Q. Chen \& L. Cai share the same host species, but they are phylogenetically distinct. Didymella sancta also differs from D. macrostoma (MFLUCC 150772) in having, macro- and micropycnidia with thick- walled, large chlamydospores and relatively short conidia (D. sancta 5-7 $\mu \mathrm{m} ;$ D. macrostoma 6-11 $\mu \mathrm{m}$ conidia).



Fig. 9 - Asexual morph of Boeremia galiicola. a Top view of colony on PDA. b Reverse view of colony. c, d Conidiomata in culture. e Squashed conidioma. $\mathrm{f}$, g Conidiogenous cells. h Conidia. Scale bars: $\mathrm{a}, \mathrm{b}=3 \mathrm{~cm}, \mathrm{c}=500 \mu \mathrm{m}, \mathrm{e}=100 \mu \mathrm{m}, \mathrm{f}-\mathrm{h}=10 \mu \mathrm{m}$.

Epicoccum mackenziei Jayasiri, Camporesi \& K.D. Hyde, sp. nov.

Index Fungorum number: IF552362, Facesoffungi number: FoF 02503

Figs 12-13 

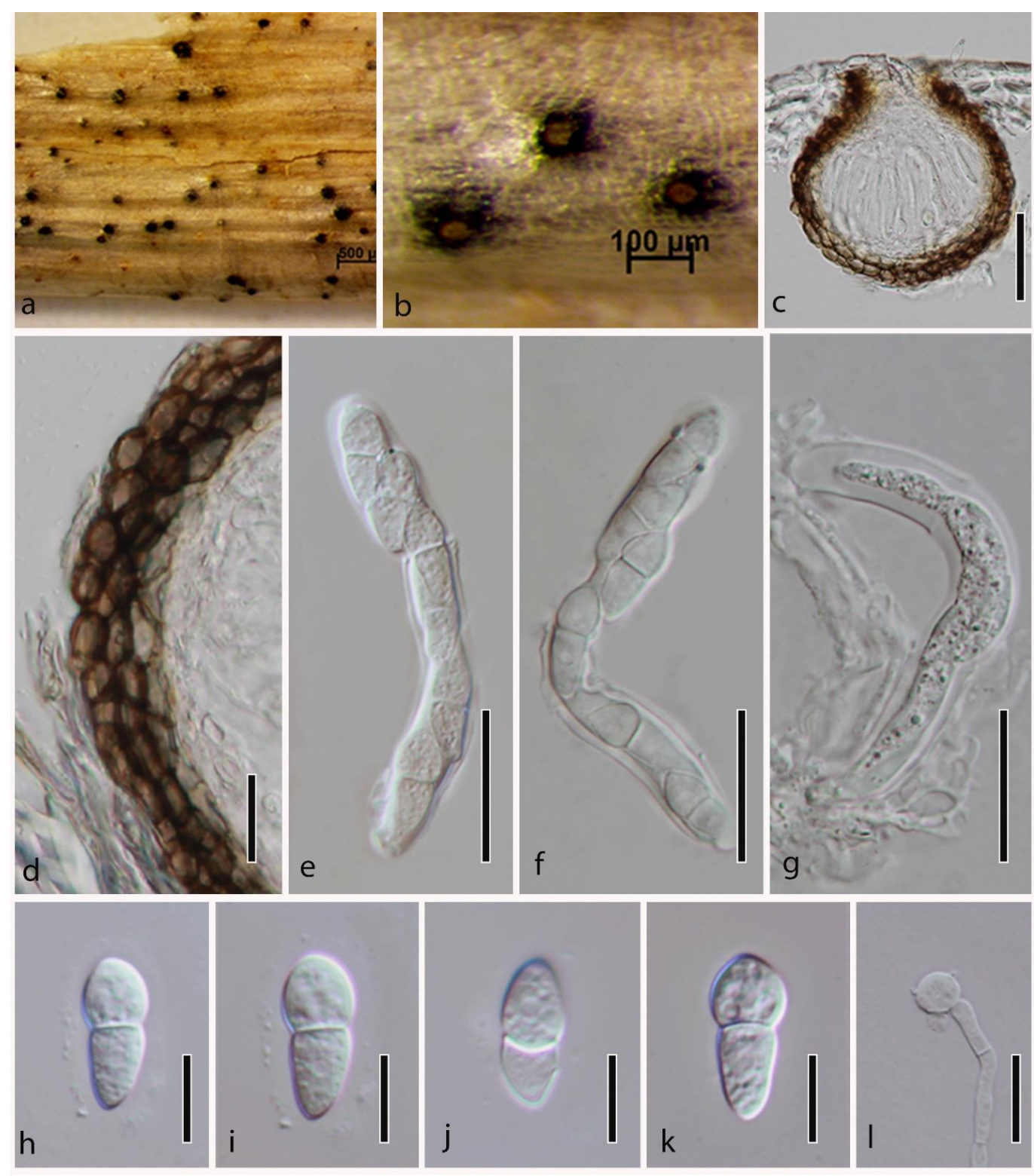

Fig. 10 - Didymella macrostoma. a, b Ascomata on host surface. c Section through ascoma. d Peridium. e-g Asci. h-k Ascospores. 1 Germinated ascospore. Scale bar: $\mathrm{c}=50 \mu \mathrm{m}, \mathrm{d}=20 \mu \mathrm{m}$, $\mathrm{e}-\mathrm{g}=30 \mu \mathrm{m}, \mathrm{h}-\mathrm{l}=10 \mu \mathrm{m}$. microfungi

Etymology: With reference to Dr. Eric McKenzie for his contribution to the study of

Holotype: MFLU 15-2601

Fungicolous or saprobic on dead stem of Ononis spinosa. Sexual morph: Ascomata 250-270 $\mu \mathrm{m}$ high $\times 205-245 \mu \mathrm{m}$ width $(\bar{x}=260 \times 230 \mu \mathrm{m}, \mathrm{n}=10)$, immersed or superficial, globose, conical globose to lenticular, scattered or clustered, papillate or apapillate, ostiolate. Peridium 32-55 $\mu \mathrm{m}$ thick, composed of several layers of brown to hyaline cells of textura angularis, fusing at the outside with the host ascomata. Hamathecium with 1.5-2 $\mu \mathrm{m}$ wide, dense, filamentous, septate, branching and hyaline, cellular pseudoparaphyses. Asci 85-120 $\times$ 6.5-15 $\mu \mathrm{m}(\bar{x}=99.4 \times 11.3 \mu \mathrm{m}, \mathrm{n}=20), 8$-spored, bitunicate, fissitunicate, clavate to cylindrical, 


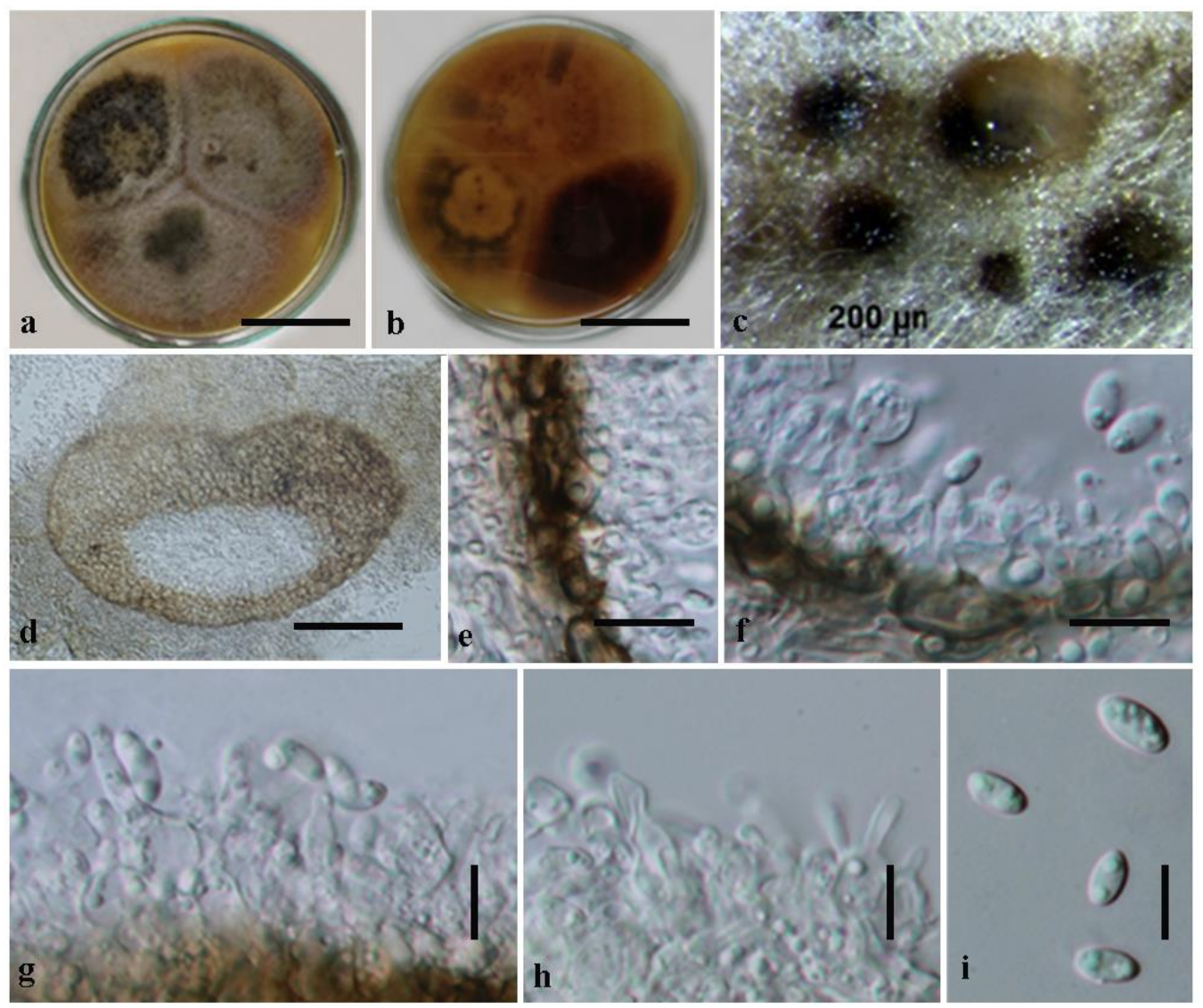

Fig. 11 - Asexual morph of Didymella macrostoma (from culture). a Top view of colony on PDA. b Reverse view of colony. c Conidiomata in culture. d Section through conidioma. e Cells of conidiomata wall. $\mathrm{f}-\mathrm{h}$ Conidiogenous cells. i Conidia. Scale bars: $\mathrm{a}, \mathrm{b}=4 \mathrm{~cm}, \mathrm{~d}=100 \mu \mathrm{m}$, e, $\mathrm{f}$ $=20 \mu \mathrm{m}, \mathrm{g}-\mathrm{i}=10 \mu \mathrm{m}$.

short-pedicellate, rounded at apex, with an ocular chamber. Ascospores $21-25 \times 2-6 \mu \mathrm{m}(\bar{x}=$ $23.5 \times 4.3 \mu \mathrm{m}, \mathrm{n}=20$ ), overlapping 2-3-seriate, cylindrical to cylindric-clavate, hyaline, 1-3septate, constricted at middle septum, containing up to four refractive oil globules, irregular, hyaline, gelatinous sheath observed when mounted in Indian ink. Asexual morph: Not observed conidiomata in culture. Chlamydospores 9-16 $\mu \mathrm{m} \times 7-15 \mu \mathrm{m}(\bar{x}=13 \times 12 \mu \mathrm{m}, \mathrm{n}=20)$, variable, irregular, unicellular or multicellular, intercalary or terminal, solitary or in chains, smooth, verruculose or incidentally tuberculate, subhyaline to dark brown, when multicellular globose or irregular-shaped (Fig. 13).

Culture characters - Ascospores germinated producing germ tubes near the septa on MEA within $24 \mathrm{~h}$. Colonies reaching $20 \mathrm{~mm}$ diam. after 5 days at $25^{\circ} \mathrm{C}$, irregular at margin, white to olivaceous grey, with white mycelial groups in the colony, middle black gummy substances (chlamydospores).

Material examined - ITALY, Province of Forlì-Cesena [FC], near Passo dei Mandrioli Bagno di Romagna, on dead aerial stem of Ononis spinosa L. (Fabaceae), 31 August 2015, Erio Camporesi IT 2593 (MFLU 15-2601, holotype), (isotype in PDD), ex-type cultures, MFLUCC 16-0335; KUMCC 16-0071; BCC GenBank accession numbers LSU: KX698028, ITS: KX698039, RPB2: KX698035, $\beta$-TUB: KX698032. 

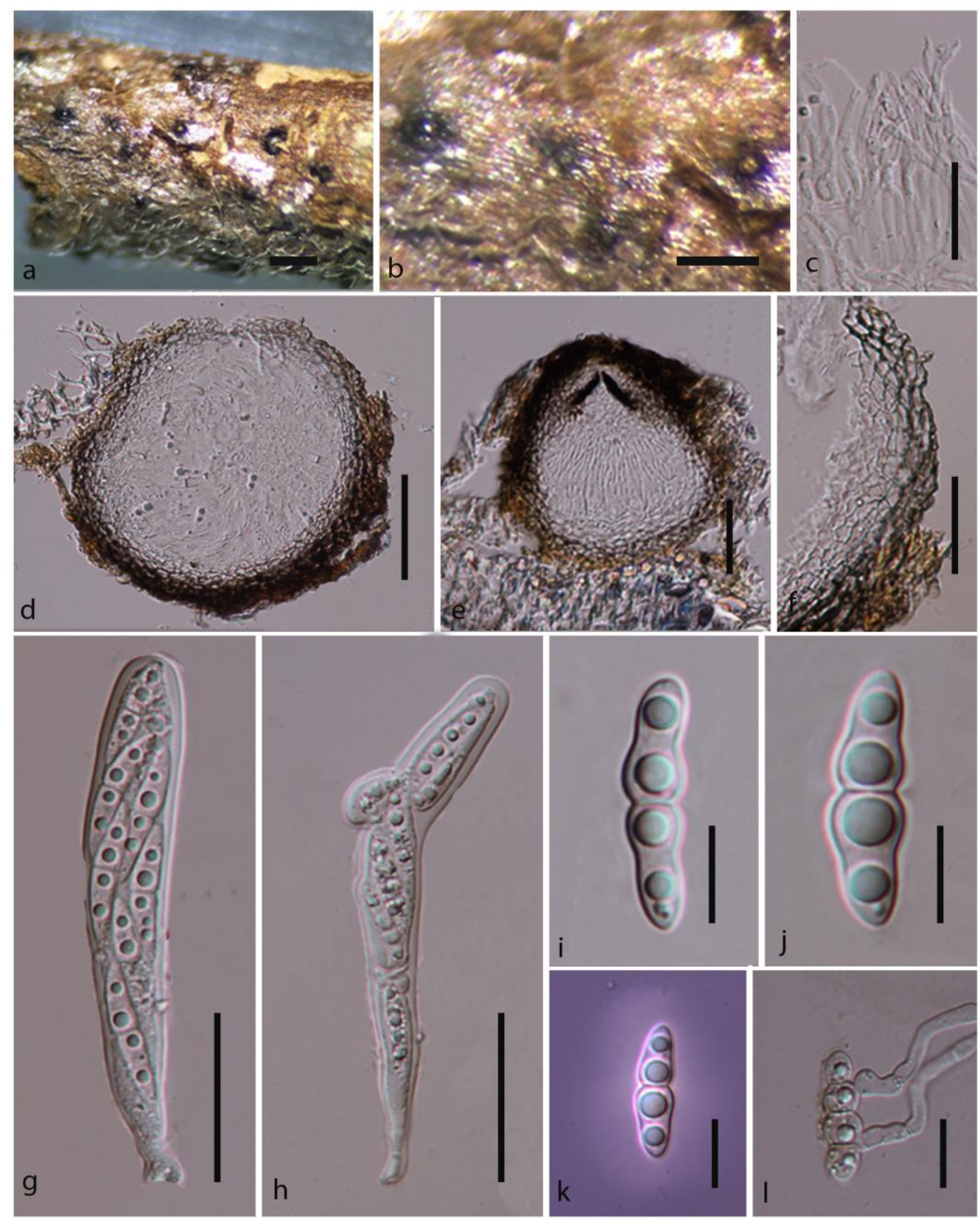

Fig. 12 - Epicoccum mackenziei (holotype). a, b Ascomata on host surface. c Pseudoparaphyses. $\mathrm{d}$, e Section through ascomata. f Peridium. g, h Asci. i-j Ascospores. k Ascospore in Indian ink. 1 Germinated ascospore. Scale bars: $\mathrm{a}, \mathrm{b}=500 \mu \mathrm{m}, \mathrm{c}=10 \mu \mathrm{m}, \mathrm{d}, \mathrm{e}=100 \mu \mathrm{m}, \mathrm{f}=50 \mu \mathrm{m}, \mathrm{g}-\mathrm{h}=30$ $\mu \mathrm{m}, \mathrm{i}-\mathrm{l}=10 \mu \mathrm{m}$.

Notes - This fungus was found as the sexual morph in nature and as chlamydospores in culture. This species fits with the generic concept of Epicoccum in having variable and irregular, multicellular, intercalary or terminal subhyaline chlamydospores in chains (Punithalingam et al. 1972, Boerema et al. 2004, Aveskamp et al. 2010). There is no previous record regarding the sexual morph of this genus. Multigene DNA sequences indicate that Epicoccum mackenziei is phylogenetically distinct from other species and its distinctiveness is highly supported (100\% MLBS/1.00 PP, 98\% MLBS/1.00 BPP, respectively) from E. nigrum Link (CBS 125.82, CBS 
173.73) and E. pimprinum (P.N. Mathur, S.K. Menon \& Thirum.) Aveskamp, de Gruyter \& Verkley (PD 77/1028, CBS 246.60). Epicoccum pimprinum and E. nigrum have 72 and 66 base pair differences within the RPB2 DNA sequence when compared to E mackenziei respectively. Unfortunately, there are no further characters to compare these taxa as this is the first record of a sexual morph and only chlamydospores were observed in culture. This is also the first record of an Epicoccum species from an Ononis host (Fabaceae) (Chen et al. 2015, Farr et al. 2017).

Epicoccum has a hyphomycetous synanamorph (Chen et al. 2015) which is characterized by dark sporodochia with branched conidiophores and mono- to polyblastic, colourless conidiogenous cells that produce coloured, sometimes verruculose, dictyoconidia (Seifert et al. 2011). The other synanamorph known for the genus is a coelomycetous one, characterized by formation of conidia in pycnidial conidiomata (Chen et al. 2015).

\section{Discussion}

The phenotypic concept based on morphological and physiological characteristics was the classic approach for delimiting species (Inui et al. 1965, Guarro et al. 1999). The use of morphology and host specificity to recognize plant-associated fungi may have resulted in the description of an excessive number of species, with few character differences (Hibbett et al. 2007). The generic concept of Phoma is broadly defined, with nine sections being recognized based on morphological characters (de Gruyter et al. 2009). Species belonging to the genus Phoma and related coelomycetes are often encountered as serious plant pathogens (de Gruyter et al. 2009, Chen et al. 2015). Furthermore, it has been suggested that the Phoma classification system could be improved by adding DNA phylogenetic data, and delineating more natural groups (Grondona et al. 1997, Torres et al. 2005). Chen et al. 2015 was prompted by the question of how to delineate natural genera in the Ascochyta-Didymella-Phoma complex, which represents a dilemma to plant pathologists and mycologists alike (Chilvers et al. 2009, Aveskamp et al. 2010, Hyde et al. 2013). Recent studies such as those of Aveskamp et al. (2010), de Gruyter et al. (2009) and Chen et al. (2015), have revised the classification of the Didymellaceae by using combined multi-locus data of ITS, LSU, RPB2 and $\beta$-TUB in their phylogenetic analyses.

In this study, we provide phylogenetic trees for Ascochyta, Boeremia, Didymella and Epicoccum using as much vouchered sequence data as possible. Two new species and two new records are proposed herein with support from our analyses of ITS, LSU, RPB2 and $\beta$-TUB sequence data. Boeremia galiicola is phylogenetically distinct from other Boeremia species with close phylogenetic affinity to Boeremia lycopersici (2, 3 and 12 base pair differences within LSU, ITS and $\beta$-TUB regions, respectively). Boeremia galiicola shares same ascomatal, features asci and ascospores characters with B. lycopersici, however, it differs in lacking the ostiole, peridium and hamathecial characters of $B$. lycopersici. Berner et al (2015) also investigated the phylogeny of Boeremia exigua var. rhapontica based on actin, $\beta$-TUB, calmodulin, elongation factor, and ITS genes. However, we also obtained the same topology using ITS, LSU, RPB2 and $\beta$-TUB genes as did Chen et al (2015). Epicoccum mackenziei is the first sexual morph recorded for the genus Epicoccum in nature and only chlamydospores were observed in the culture. Therefore, this species is introduced based on the sexual morph and phylogenetic data. Epicoccum mackenziei is phylogenetically distinct from E. nigrum and E. pimprinum with high statistical support. Our Ascochyta species (formerly Phoma medicaginis) is a new collection of Ascochyta medicaginicola (Boerema et al. 2004, Chen et al. 2015) from Russia on Melilotus albus. This collection further substantiates a host parasite specialization of this fungus on 
Melilotus albus (Fabaceae). The multigene phylogenetic analysis shows that this species groups in the Ascochyta medicaginicola clade with high statistical support. In addition, there are morphological similarities in conidial and ascomatal characters that support its inclusion in Ascochyta medicaginicola. However, this is the first record of an Ascochyta species from Russia and it differs from As. nigripynidia by having septate conidia, country of origin and host genus (Vicia, Fabaceae). Our Didymella isolate is phylogenetically close to D. macrostoma with only three base pair differences in the RPB2 sequenced region. In addition, they share similar features in having globose to irregular confluent pycnidia, globose to bottle-shaped conidiogenous cells, and subglobose to ellipsoidal, hyaline ascospores with guttules. Therefore, in this study our isolate is maintained as a new record of D. macrostoma from Italy.

The present study indicates that the total number of Didymellaceae species is possibly high and warrants further investigations, and this could be considered as a step towards a systematic research of Didymellaceae in temperate areas such as Europe and Russia.

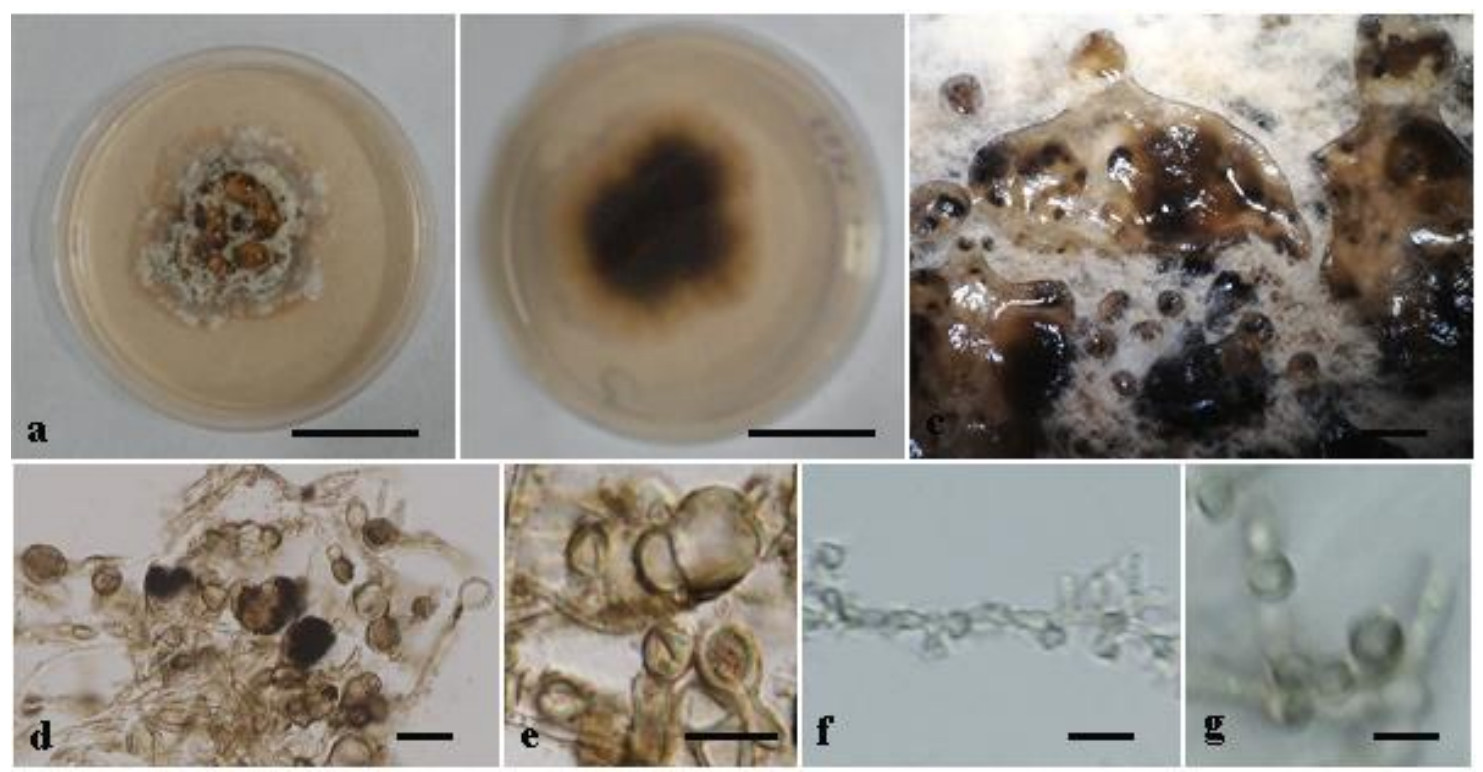

Fig. 13 - Epicoccum mackenziei (ex-type culture). a Top view of colony on PDA. b Reverse view of colony. c Asexual structures in culture. $\mathrm{d}-\mathrm{g}$ Chlamydospores in culture. Scale bars: a, b $=2 \mathrm{~cm}, \mathrm{c}=500 \mu \mathrm{m}, \mathrm{d}, \mathrm{e}=10 \mu \mathrm{m}, \mathrm{f}, \mathrm{g}=5 \mu \mathrm{m}$.

\section{Acknowledgements}

K.D. Hyde thanks the Chinese Academy of Sciences, [project number 2013T2S003] for the award of Visiting Professorship of Senior International Scientists at Kunming Institute of Botany as well as Chiang Mai University for a Visiting Professorship. The authors thank the National Natural Science Foundation of China (NSFC Grants Nos. 31670027 \& 31460011 \& 30870009) for supporting and funding this research. We thank Guizhou University, China for assistance with the molecular work. MFLU is thanked for supporting studies on Dothideomycetes [grant number 56101020032]. We are grateful to the Mushroom Research Foundation, Chiang Rai, Thailand for support. The authors thank Dr. Shaun Pennycook from Landcare Research University of Auckland, New Zealand, for nomenclatural advice on the proposed name, Dr. Alan Phillips from University of Lisbon, Portugal, helping for check the 
alignment files, and Xiaoya Ma and Dr. Ting-Chi Wen from Guizhou University, China, for help with sequence data analyses and Mr. T.S. Bulgakov from Academy of Biology and Biotechnology, Southern Federal University, Russia for sending the specimens. The University of Mauritius is acknowledged for support and Dr Rajesh Jeewon thanks MFU for the offer of a short term Visiting Professor in 2017.

\section{References}

Aveskamp MM, de Gruyter J, Woudenberg JHC, Verkley G.M et al. 2010 - Highlights of the Didymellaceae: a polyphasic approach to characterise Phoma and related pleosporalean genera. Studies in Mycology 65, 1-60.

Berner D, Cavin C, Woudenberg JHC, Tunali B et al. 2015 - Assessment of Boeremia exigua var. rhapontica, as a biological control agent of Russian knapweed (Rhaponticum repens) Biological Control 81, 65-75

Boerema GH, de Gruyter J, Noordeloos ME, Hamers MEC. 2004 - Phoma identification manual. Differentiation of specific and infra-specific taxa in culture. CABI Publishing, Wallingford, UK.

Chen Q, Jiang GR, Zhang GZ, Cai L, Crous PW. 2015 - Resolving the Phoma enigma. Studies in Mycology 82, 137-217.

Chilvers MI, Rogers JD, Dugan FM, Stewart JE et al. 2009 - Didymella pisi sp. nov., the teleomorph of Ascochyta pisi. Mycological Research 113, 391-400.

Chomnunti P, Hongsanan S, Hudson BA, Tian Q et al. 2014 - The sooty moulds. Fungal Diversity 66, 1-36.

Cooke MC. 1885 - New British fungi. Grevillea. 13, 89-100.

De Gruyter J, Aveskamp MM, Woudenberg JHC, Verkley GJM et al. 2009 - Molecular phylogeny of Phoma and allied anamorph genera: towards a reclassification of the Phoma complex. Mycological Research 113, 508-519.

Farr DF, Rossman AY 2017 - Fungal Databases, U.S. National Fungus Collections, ARS, USDA. Retrieved February 26, 2017, from https://nt.ars-grin.gov/fungaldatabases/

Grondona I, Monte E, Garcia-Acha I, Sutton BC 1997 - Pyrenochaeta dolichi: an example of a confusing species. Mycological Research 101, 1405-1408.

Guarro J, Gené J, Stchigel AM 1999 - Developments in fungal taxonomy. Clinical Microbiology Reviews 12, 454-500.

Index Fungorum 2017 - http://www.indexfungorum.org/Names/IndexFungorumRegister.htm (May, 2017)

Inui T, Takeda Y, Iizuka H 1965 - Taxonomical studies on genus Rhizopus. Journal of General and Applied Microbiology 11, 1-121

Huelsenbeck JP, Ronquist F. 2001 - MRBAYES: Bayesian inference of phylogenetic trees. Bioinformatics 17, 754-755.

Hyde KD, Jones EBG, Liu JK, Ariyawansa HA et al. 2013 - Families of Dothideomycetes. Fungal Diversity 63, 1-313.

Jayasiri SC, Hyde KD, Ariyawansa HA, Bhat J et al. 2015 - The faces of fungi database: fungal names linked with morphology, phylogeny and human impacts. Fungal Diversity 74, $3-$ 18.

Jellis GJ, Punithalingam E. 1991 - Discovery of Didymella fabae sp. nov., the teleomorph of Ascochyta fabae, on faba bean straw. Plant Pathology 40, 150-157. 
Jeewon R, Hyde KD 2016 - Establishing species boundaries and new taxa among fungi: recommendations to resolve taxonomic ambiguities. Mycosphere 7, 1669-1677

Jeewon R, Liew ECY, Hyde KD. 2002 - Phylogenetic relationships of Pestalotiopsis and allied genera inferred from ribosomal DNA sequences and morphological characters. Molecular Phylogenetics and Evolution 25, 378-392.

Jeewon R, Liew ECY, Simpson, JA, Hodgkiss, IJ, Hyde KD 2003 - Phylogenetic significance of morphological characters in the taxonomy of Pestalotiopsis species. Molecular Phylogenetics and Evolution 27, 372-383.

Kaiser WJ, Wang BC, Rogers JD. 1997 - Ascochyta fabae and A. lentis: host specificity, teleomorphs (Didymella), hybrid analysis, and taxonomic status. Plant Disease 81, 809816.

Liu YJ, Whelen S, Hall BD. 1999 - Phylogenetic relationships among ascomycetes: evidence from an RNA polymerase II subunit. Molecular Biology and Evolution 16, 1799-1808.

Miller MA, Pfeiffer W, Schwartz T. 2010 - Creating the CIPRES Science Gateway for inference of large phylogenetic trees. In: Proceedings of the Gateway Computing Environments Workshop (GCE), 14 Nov 2010, New Orleans, LA.

Nylander JAA. 2004 - MrModeltest 2.0. Program distributed by the author. Evolutionary Biology Centre, Uppsala University

Punithalingam E, Tulloch M, Leach CM. 1972 - Phoma epicoccina sp. nov. on Dactylis glomerata. Transactions of the British Mycological Society 59, 341-345.

Rannala B, Yang Z 1996 - Probability distribution of molecular evolutionary trees: a new method of phylogenetic inference. Journal of molecular evolution 43, 304-311.

Rambaut A, Drummond A. 2008 - FigTree: Tree figure drawing tool, version 1.2. 2. Institute of Evolutionary Biology, University of Edinburgh.

Rambaut A, Drummond AJ. 2007 - Tracer, version 1.5.

Seifert K, Morgan-Jones G, Gams W, Kendrick B. 2011 - The genera of hyphomycetes. CBS Biodiversity Series no. 9: 1-997. CBS-KNAW Fungal Biodiversity Centre, Utrecht, Netherlands

Stamatakis A, Hoover P, Rougemont J. 2008 - A rapid bootstrap algorithm for the RAxML webservers. Systematic biology 75, 758-771.

Sung GH, Sung J-M, Hywel-Jones NL, Spatafora JW. 2007- A multi-gene phylogeny of Clavicipitaceae (Ascomycota, Fungi): identification of localized incongruence using a combinational bootstrap approach. Molecular Phylogenetics and Evolution 44, 12041223.

Thambugala KM, Daranagama DA, Phillips AJ, Bulgakov TS et al. 2017 - Microfungi on Tamarix. Fungal Diversity 82, 239-306

Torres MS, White JF, Cazares G, Bergen M et al. 2005 - A new species and its phylogenetic placement in the Didymella/Phoma complex (Phaeosphaeriaceae, Pleosporales). Mycotaxon 93, 297-308.

Trapero-Casas A, Kaiser WJ. 1992 - Development of Didymella rabiei, the teleomorph of Ascochyta rabiei, on chickpea straw. Phytopathology 82, 1261-1266.

Vilgalys R, Hester M. 1990 - Rapid genetic identification and mapping of enzymatically amplified ribosomal DNA from several Cryptococcus species. Journal of Bacteriology $172,4239-4246$.

Wijayawardene DNN, McKenzie EHC, Chukeatirote E, Wang Y, Hyde KD 2012a Coelomycetes. Cryptogamie Mycologie 33(3), 215-244. 
Wijayawardene DNN, McKenzie EHC, Hyde KD 2012b - Towards incorporating anamorphic fungi in a natural classification - checklist and notes for 2011. Mycosphere 3, 157-228

Wijayawardene NN, Crous PW, Kirk PM. 2014 - Naming and outline of Dothideomycetes 2014 including proposals for the protection or suppression of generic names. Fungal Diversity $69,1-55$.

Wijayawardene NN, Hyde KD, Wanasinghe DN, Papizadeh M et al. 2016 - Taxonomy and phylogeny of dematiaceous coelomycetes. Fungal Diversity 77, 1-316.

White TJ, Bruns T, Lee S, Taylor J. 1990 - Amplification and direct sequencing of fungal ribosomal RNA genes for phylogenetics. In: Innis MA, Gelfand DH, Sninsky JJ, White TJ (eds) PCR protocols: a guide to methods and applications, Academic, San Diego, 315322.

Woudenberg JHC, Aveskamp MM, de Gruyter J, Spiers AG et al. 2009 - Multiple Didymella teleomorphs are linked to the Phoma clematidina morphotype. Persoonia 22, 56-62

Zhaxybayeva O, Gogarten JP. 2002 - Bootstrap, Bayesian probability and maximum likelihood mapping: exploring new tools for comparative genome analyses. BMC Genomics 3, 4 .

Zheng L, Xi P, Si Tu JJ, Chen XN. 2017 - First report of Phoma herbarum causing leaf spot of oil palm (Elaeis guineensis) in China. Plant Disease. 